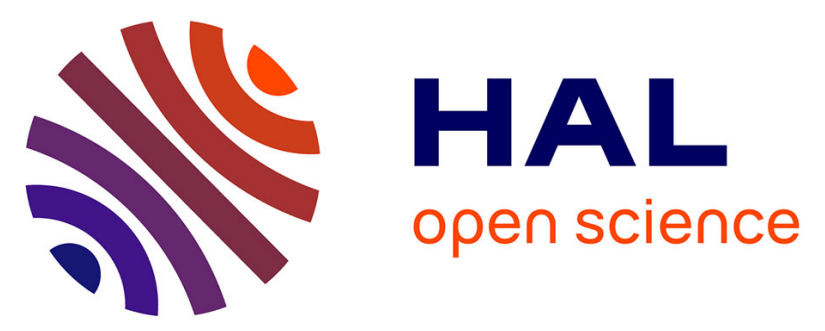

\title{
Importance of oral phase in in vitro starch digestibility related to wholegrain versus refined pastas and mastication impairment
}

S. Blanquet-Diot, O. François, S. Denis, M. Hennequin, Marie-Agnès Peyron

\section{- To cite this version:}

S. Blanquet-Diot, O. François, S. Denis, M. Hennequin, Marie-Agnès Peyron. Importance of oral phase in in vitro starch digestibility related to wholegrain versus refined pastas and mastication impairment. Food Hydrocolloids, 2021, 112, pp.106277. 10.1016/j.foodhyd.2020.106277 . hal-02976589

\section{HAL Id: hal-02976589 \\ https://hal.inrae.fr/hal-02976589}

Submitted on 23 Oct 2020

HAL is a multi-disciplinary open access archive for the deposit and dissemination of scientific research documents, whether they are published or not. The documents may come from teaching and research institutions in France or abroad, or from public or private research centers.
L'archive ouverte pluridisciplinaire HAL, est destinée au dépôt et à la diffusion de documents scientifiques de niveau recherche, publiés ou non, émanant des établissements d'enseignement et de recherche français ou étrangers, des laboratoires publics ou privés.

\section{(ㅇ)(1) $\$$}

Distributed under a Creative Commons Attribution - NonCommercial - NoDerivatives 44.0 


\title{
Importance of oral phase in in vitro starch digestibility related to wholegrain versus refined pastas and mastication impairment
}

\author{
S. Blanquet-Diot ${ }^{\mathrm{a}}$, O. François ${ }^{\mathrm{b}}$, S. Denis ${ }^{\mathrm{a}}$, M. Hennequin ${ }^{\mathrm{b}}$, M.A. Peyron ${ }^{\mathrm{c}, *}$ \\ ${ }^{a}$ Université Clermont Auvergne, INRAE, MEDIS, F-63000, Clermont-Ferrand, France \\ ${ }^{\mathrm{b}}$ Université Clermont Auvergne, CHU Clermont-Ferrand, CROC, F-63000, Clermont-Ferrand, France \\ ${ }^{\mathrm{c}}$ Université Clermont Auvergne, INRAE, UNH, F-63000, Clermont-Ferrand, France
}

\section{A R T I C L E I N F O}

\section{Keywords:}

In vitro

Mastication

Digestion

Starch digestibility

Deficient mastication

Type of pastas

\begin{abstract}
A B S T R A C T
Starch represents the main source of carbohydrates in human diet and its digestibility is suspected to be involved in the control of glycemic response. The low glycemic index caused by pastas is mainly attributed to the starchprotein network constituting their compact structure. A significant part of the physico-chemical digestive process probably occurs during mastication with exposure to amylase. However, the respective accountability of oral and intestinal phases in digestion is not clearly established, and this knowledge would especially benefit to health management of people suffering of impaired mastication. Food boluses were produced for in vitro gastrointestinal digestion either by in vitro normal (NM) or deficient mastication (DM) of wholegrain and refined pastas. Boluses were first characterized for physical properties. Many large particles were obtained in DM boluses whatever the pastas. Starch and hydrolysis products were then determined in boluses and gastrointestinal digestas. The beginning of starch hydrolysis was confirmed in the mouth with a production of maltose in the NM boluses, around $1.6 \mathrm{~g} / 100 \mathrm{~g}$ of cooked pastas, significantly decreased to $1.2 \mathrm{~g} / 100 \mathrm{~g}$ in the DM boluses, whatever the pastas. Even if the negative effect of DM on gastrointestinal starch hydrolysis into glucose was observed for both pastas, the greatest impact occurred in refined ones with $55.9 \pm 0.82 \mathrm{~g}$ glucose $/ 100 \mathrm{~g}$ pastas after NM versus $53.00 \pm 0.95 \mathrm{~g} / 100 \mathrm{~g}$ after DM. This study highlighted the importance to consider the oral phase in digestion studies, regarding the impact of food structure and oral disruption, and especially in case of DM.
\end{abstract}

\section{Introduction}

As a polysaccharide found in the tissues of many plants used in food, starch represents the main source of carbohydrates in human diet offering many staple foods such as pastas, bread, rice or potato. Starch is a functional polymer characterized by gelatinization properties, gelling capacity and water binding giving it a prominent place in a wellbalanced diet, all the more because starch is often used in combination with other hydrocolloids and proteins to modify rheological and functional properties of a food system (Gao et al., 2017). Considering that starch is widely used in food, exploitation of maximal knowledge in food formulation and processing for dietary benefits, in light of food digestion and absorption mechanisms, should be considered (Norton, Wallis, Spyropoulos, Lillford, \& Norton, 2014). For example, diet awareness for treatment of various disorders such as diabetes, gluten disorders, malnutrition in elderly, weight management, well-being, or disease prevention, has led to a rise in the development of new functional foods with hydrocolloids as texture agents used as replacers of fat or gluten (Funami, 2011; Nishinari, 2009). However, this approach requires better knowledge on the relationship between food characteristics, its transformation during oral processing and its consequence on digestion.

Starchy foods can be classified according to their digestibility into rapidly or slowly digestible, or resistant starch, which is generally defined on the basis of the amplitude and duration of the associated glycemic response (Englyst, Kingman, \& Cummings, 1992; Miao, Jiang, Cui, Zhang, \& Jin, 2015). Studies on various starchy foods have clearly established, both in vivo and in vitro, that particle size (Al-Rabadi, Gilbert, \& Gidley, 2009; Bornhorst, Kostlan, \& Singh, 2013), starch source, degree of starch gelatinization (Björck, Granfeldt, Liljeberg, Tovar, \& Asp, 1994; Cummings \& Englyst, 1995; Parada \& Aguilera, 2009), physico-chemical nature of the food matrix, food composition, and processing (Björck et al., 1994; Bornhorst \& Singh, 2014; Granfeldt \& Björck, 1991; Jenkins et al., 1983; Pentikäinen et al., 2014), have a

\footnotetext{
* Corresponding author. INRAE, Human Nutrition Unit, Theix, F-63122, Saint Genès Champanelle, France.

E-mail address: marie-agnes.peyron@inrae.fr (M.A. Peyron).
} 
substantial impact on starch digestibility and the glycemic index. Compared to many other starchy foods, the relatively slow starch digestion in pastas is commonly attributed to a limited enzyme accessibility due to a compact and dense structure, entrapment of starch granules in gluten network, nature of polymers and starch-protein interactions (Kim et al., 2008; Zou, Sissons, Gidley, Gilbert, \& Warren, 2015; Zou, Sissons, Warren, Gidley, \& Gilbert, 2016). Food glycemic potential is thus dependent on the actions of digestive function on food structure, and foremost on oral food fragmentation.

Food matrix disorganization begins during mastication producing smaller particles mixed with saliva to form the swallowable food bolus. Salivary alpha-amylase already demonstrated its capacity to hydrolyze starch during mastication and oral exposure and early gastric digestion (Freitas, Feunteun, Panouillé, \& Souchon, 2018; Hoebler et al., 1998; Pentikäinen et al., 2014). Even if this enzymatic activity has been described a long time ago, its actual contribution to overall starch digestion still remains an existing topic since oral functions are important in feeding behavior. Indeed, its contribution to carbohydrate digestion have to be better investigated in link with the level of particle size reduction that influences the surface of contact between food and saliva. Actually, the particle size has already been demonstrated to influence in vivo and in vitro starch digestibility (Alam et al., 2019; Hoebler et al., 1998; Ranawana, Henry, \& Pratt, 2010; Ranawana, Monro, Mishra, \& Henry, 2010) but a deficient mastication providing an inadequate food fragmentation during mastication may impede the initiation of oral starch digestion.

The consequences of deficient mastication on nutrition are not fully described, despite the fact that an impaired oral state has long been repeatedly suggested, but never confirmed, as a causal factor in slowing, if not impairing, digestion. Characterizing the consequences of deficient food oral processing would be useful to design appropriate foods to maintain safe masticatory strategies. This work aimed at analyzing the influence of both the food matrix and a deficient mastication on oral and intestinal steps in pasta starch digestion. To achieve this goal, in vitro normal and deficient mastication, and static in vitro digestion experiments were performed with wholegrain and refined pastas. Respective impact of type of pastas and mastication performance were analyzed in terms of food bolus properties and level of starch digestibility after mastication and gastrointestinal (GI) digestion.

\section{Materials and methods}

\subsection{Pasta products}

Commercial Fusilli pastas made from refined ("refined pastas") and wholegrain ("wholegrain pastas") durum-wheat semolina were used (Panzani ${ }^{\circledR}$ and Carrefour ${ }^{\circledR}$ brands, respectively). Both types of Fusilli pastas exhibited the same helix shape and dimensions. The pastas were cooked in cold water for their optimal cooking time (10 min for refined pastas and $13 \mathrm{~min}$ for wholegrain pastas) using a microwave oven (1000 Watts). The cooked pastas were drained and experimental samples of $7 \mathrm{~g}$ were prepared for each mastication assay.

\subsection{Masticatory experiments}

In vitro masticatory experiments were performed with the $\mathrm{AM}^{2}$ masticatory apparatus ("Artificial Mastication Advanced Machine") designed and validated to produce boluses with granulometric properties similar to those of boluses collected in in vivo normal mastication ((Mishellany-Dutour et al., 2011; Peyron et al., 2019; Peyron, Santé-Lhoutellier, François, \& Hennequin, 2018; Woda, Mishellany-Dutour, et al., 2010). As explained in these works, programming the masticatory apparatus is always based on preliminary in vivo mastication experiments providing data on the dynamic parameters of the masticatory sequence and permitting particle size distribution (PSD) analysis of the in vivo expectorated food bolus. This was done in the present study for pasta products in young subjects $(n=8)$ presenting good oral health, natural dentition and healthy mastication (local Ethical agreement CE-CIC-GREN-10/06-\#5044). After normal mastication (NM), the PSD of the collected food boluses was analyzed by sieving and was considered as the reference curve to reach during the programming step. The dynamic in vivo data were used to program the $\mathrm{AM}^{2}$ masticator apparatus and other mechanical parameters were progressively adjusted by comparison between in vivo and in vitro granulometric curves until they were superimposed. Artificial saliva containing $261 \mathrm{UI} / \mathrm{mL}$ of alpha-amylase from porcine pancreas (A3176 Sigma ${ }^{\circledR}$, France) and 2.16 $\mathrm{g} / \mathrm{L}$ of mucin from porcine stomach type II (M2378 Sigma ${ }^{\circledR}$, France) in mineral water (Volvic $\AA$, France) was introduced $(1 \mathrm{~mL})$ at the beginning of the masticatory sequence (Roger-Leroi, Mishellany-Dutour, Woda, Marchand, \& Peyron, 2012). As observed in vivo, the temperature of the masticatory chamber was regulated at $36^{\circ} \mathrm{C}$. The second series of the in vitro masticatory task was the simulation of a poorly formed food bolus resulting from deficient mastication (DM). As widely described in the literature, the main indicator of DM is an insufficiently fragmented food sample and poorly formed food bolus always composed of a substantial proportion of large particles, whatever the cause of the masticatory deficiency (Peyron et al., 2018; Woda, Nicolas, et al., 2010; Woda, Mishellany, \& Peyron, 2006). By performing a lower number of in vitro masticatory cycles, the food bolus produced was insufficiently fragmented and simulated the result of an average defective masticatory sequence (Woda, Nicolas, et al., 2010). Thus, after these programming steps, the masticator apparatus was capable of producing both well-formed and poorly formed food boluses. Immediately after the end of the NM and DM masticatory sequences, the boluses were collected and subjected to mechanical characterization (granulometric and physical analyses), used to measure starch, maltose and glucose contents, or subjected to further static in vitro GI digestion. Eight boluses in each masticatory condition were produced for granulometric analysis, five boluses for physical measurement, and three boluses were produced for determining sugar content in the liquid phase. Three other boluses were also produced for further GI digestion.

\subsection{In vitro static gastrointestinal digestion}

An adaptation of an in vitro static protocol was used to evaluate the digestibility of pastas starch after GI digestion (Thévenot et al., 2015). Forty milliliters of mineral water (Volvic $\AA$, France) was added to the pasta boluses collected in the $\mathrm{AM}^{2}$ apparatus after NM and DM of wholegrain and refined pastas. After bolus recovery, the mastication chamber was rinsed with $5 \mathrm{~mL}$ of mineral water which was then added to the previous bolus mixture. After the addition of pepsin from porcine gastric mucosa (1140 UI/mL P7012 Sigma $\left.{ }^{\circledR}\right)$, the gastric phase was performed at $37^{\circ} \mathrm{C}$ for $1 \mathrm{~h}$ at $\mathrm{pH} 3.0$ (adjusted with $1 \mathrm{~N} \mathrm{HCl).} \mathrm{Afterwards,}$ trypsin from bovine pancreas (308 UI/mL T4665 Sigma ${ }^{\circledR}$ ), pancreatin from hog pancreas (1.6 mg/L Pancreatin 4xUSP, P1750 Sigma $\left.{ }^{\circledR}\right)$ and bile extract porcine $(1.9 \mathrm{mg} / \mathrm{L}, \mathrm{B} 8631$ Sigma $\mathbb{R})$ were added to the digesta. This intestinal phase was performed at $37^{\circ} \mathrm{C}$ for $2 \mathrm{~h}$ under slight magnetic agitation at $\mathrm{pH} 7.0$ (adjusted with $1 \mathrm{M}$ sodium bicarbonate). Digestions were performed in triplicate ( 3 boluses) and GI digestas were immediately analyzed for starch, maltose and glucose contents (in duplicate).

\subsection{Mechanical characterization of food bolus}

\subsubsection{Granulometric analysis}

Particle size distribution in the pasta boluses was determined by manual dry sieving. After its in vivo or in vitro recovery, the bolus was first spilled onto a nylon cloth with a $0.3 \mathrm{~mm}$ mesh size (Sefar, Switzerland) and rinsed under cold running water for $2 \mathrm{~min}$ to eliminate saliva. The bolus was then left $70 \mathrm{~min}$ to dry at $37{ }^{\circ} \mathrm{C}$ in a slightly ventilated oven. Dried particles were manually sieved on a stack of 9 sieves of 7.1, 6.3, 4.0, 2.5, 2.0, 1.4, 1.0, 0.8 and $0.4 \mathrm{~mm}$ aperture (Saulas, 
France) and the particles retained on each sieve were weighed. For a given bolus, the weight results were expressed as the cumulative curve of particle mass falling through each sieve. From each cumulative distribution curve, the median particle size (d50), defined as the theoretical sieve through which $50 \%$ of the mass could pass, was determined (Fig. 1). This granulometric analysis was performed for all the boluses collected after NM and DM of wholegrain and refined pasta products ( 8 boluses in each condition).

\subsubsection{Physical characterization of food bolus}

The physical properties of the boluses were measured with the Texture Profile Analysis (TPA) test using an Instron machine (mini55, UK) equipped with a flat piston head ( $\varnothing 28 \mathrm{~mm}$ ), a cylindrical cup (int. $\varnothing$ $35 \mathrm{~mm}$ ) and a $500 \mathrm{~N}$ load cell. Immediately after its collection in the apparatus, the bolus was gently placed to fit the cylindrical shape of the cup. A flat cylindrical tool of $10 \mathrm{~g}$ mass was slightly layed on the bolus to homogenize the surface of contact between bolus and Instron piston. From the contact point considered as zero deformation, the bolus then underwent two successive compression cycles performed a compression ratio of $65 \%$ deformation at $50 \mathrm{~mm} / \mathrm{min}$ and a sampling frequency of 250 points/sec. The deformation rate of $65 \%$ was chosen in line with previous food bolus characterization (Peyron et al., 2018) As usually done with the TPA test, the hardness (maximal charge during the first compression), recoverability (area under the curve AUC of the second compression divided by AUC of first one), elasticity (contact time between bolus and piston during the second compression divided by the
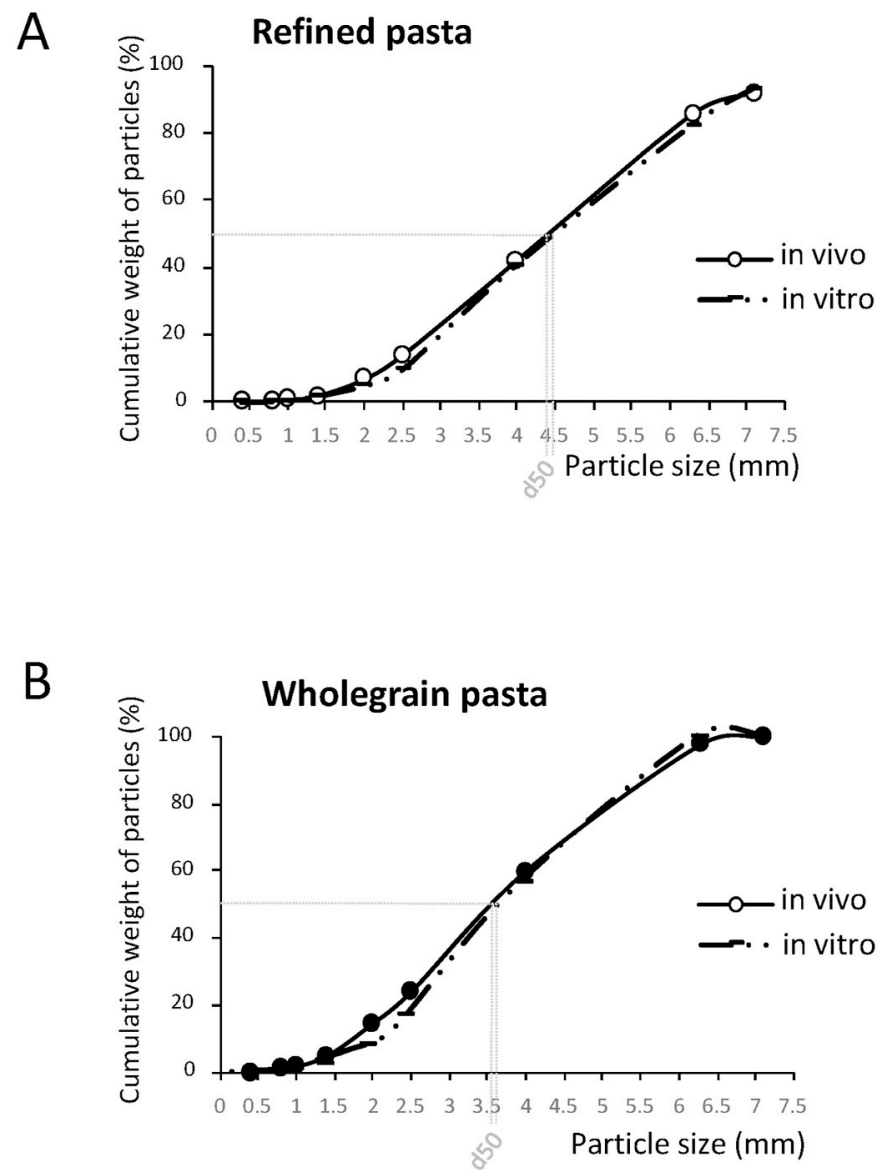

Fig. 1. Masticator apparatus programming. The overlay of mean particle size distribution curves obtained in boluses collected after normal in vivo or in vitro mastication were used to validate the programming of normal mastication (NM) on the masticator apparatus for refined (A) and wholegrain (B) pastas. Curves are presented as mean cumulative percentages of particle weight passing through each sieve ( $\mathrm{n}=8$ boluses). contact time during the first one) and adhesiveness (AUC of the pic observed during the piston rise before the second compression) values characterizing a food bolus were extracted from force-displacement curve analysis. The comparative assessment of these characteristics provided useful information on the physical properties of the boluses obtained after mastication. Five boluses were produced and characterized in each masticatory condition and for each pasta product.

\subsection{Analysis of starch digestibility}

The degree of starch hydrolysis in the pasta boluses after simulation of oral and GI digestion was assessed by determining the amount of maltose and glucose released in the liquid phase of the bolus (just after mastication) and in the GI digestas (at the end of digestion). After in vitro mastication of pastas, $10 \mathrm{~mL}$ of mineral water was added to the food boluses and pooled with the $5 \mathrm{~mL}$ of water used to rinse the mastication chamber. Amylase activity in the food boluses and digestas was immediately inhibited by decreasing the $\mathrm{pH}$ value to 3 with $1 \mathrm{~N} \mathrm{HCl}$. Food boluses and GI digestas were then centrifuged ( $\left.1 \mathrm{~min}, 2000 \mathrm{rpm}, 4^{\circ} \mathrm{C}\right)$ and the supernatants collected. The amount of starch, maltose and glucose was determined using enzymatic kits (Total Starch K-TSHK, Maltose/Sucrose/D-glucose K-MASUG, Megazyme ${ }^{\circledR}$, Irland). All the analyses were performed in duplicate and the contents were expressed in $\mathrm{g} / 100 \mathrm{~g}$ of cooked drained pastas. Mean starch digestibility after the oral phase was expressed as the amount of maltose produced in the liquid phase of the bolus compared to the initial amount of starch in pasta products (in \%, three boluses). Similarly, starch digestibility after the GI phase was expressed as the amount of glucose produced in the GI digesta compared to the initial amount of starch in the pasta products (in \%, three GI digestions).

\subsection{Data analysis}

Statistical analysis was performed with SPSS software (IBM SPSS Statistics). The normality of the distribution of the dependent variables was verified. First, to validate the programming of the masticator apparatus, One-Way repeated-measure ANOVAs were performed in a General Linear Model design (with sieves as repeated factor) to test if in vivo and in vitro particle size distribution were not significantly different for the boluses of each type of pastas. Other One-Way repeated-measures ANOVAs were performed to test if differences existed between particle size distributions measured in boluses obtained after NM and DM, and between particle size distributions obtained for the two types of pastas according to the type of masticatory sequence. Several One-Way ANOVAs were used to test the existence of difference for all the other variables characterizing the boluses collected after NM and DM and GI digestion of the two types of pastas. When a difference was observed, the mean comparison was obtained using a post-hoc Student-NewmannKeuls test carried out with a risk fixed at $5 \%$.

\section{Results}

\subsection{Characterization of pasta products}

Initial amounts of starch, maltose and glucose were first determined in cooked refined and wholegrain pastas. Non-significant differences were found between the two types of pastas for starch, maltose and glucose: in refined pastas, $67.71 \pm 0.54,0.51 \pm 0.03$ and $0.03 \pm 0.02 \mathrm{~g} /$ $100 \mathrm{~g}$ of pastas, respectively; in wholegrain pastas: $65.36 \pm 2.29,0.47 \pm$ 0.05 and $0.06 \pm 0.03 \mathrm{~g} / 100 \mathrm{~g}$ of pastas, respectively. The initial starch concentrations measured were in accordance with those mentioned by the manufacturer $(68 \%$ and $66 \%$ for refined and wholegrain pastas, respectively). 


\subsection{Programming of the masticator apparatus}

The programming of the masticator apparatus was set from in vivo mastication data. In vivo masticatory sequences of pasta products (both wholegrain and refined pastas) until swallowing were characterized by a mean of 23 masticatory cycles performed at a mean frequency of $1.55 \pm$ 0.24 cycles $/ \mathrm{sec}$. The mean weight of the pasta boluses was $7.97 \pm 0.67 \mathrm{~g}$ and an increase of $1 \mathrm{~g}$ in bolus weight due to saliva incorporation was estimated from weight comparisons. Thus, $1 \mathrm{~mL}$ artificial saliva was introduced in the masticator apparatus at the beginning of each masticatory sequence.

To simulate NM of the wholegrain and refined pasta products, the $\mathrm{AM}^{2}$ masticator apparatus was programmed to perform 23 masticatory cycles with a fine balance between shearing and compressive forces applied to the pasta products needed to form boluses with the required granulometry. The overlap of in vivo and in vitro curves confirmed that particle size distributions were not significantly different $(p>0.05)$ and that the programming of the apparatus will produce well-formed food boluses (Fig. 1). For the pasta products used, the number of masticatory cycles chosen to simulate a DM was set at half of the number of cycles realized in NM, and assumed to be representative of an average DM of pastas. Then, a DM was achieved by programming the apparatus to run only 12 masticatory cycles out of the 23 normally needed to produce a well-formed food bolus.

\subsection{Effect of type of pastas on bolus properties and starch digestibility} after in vitro normal mastication

\subsubsection{Physical characterization of food boluses after normal mastication}

Particle size distribution in the swallowable boluses collected after in vitro NM was significantly different according to the type of pastas $(\mathrm{p}=$ 0.017, Fig. 2). This was confirmed by a significant difference observed between d50 values with $4.5 \pm 0.7 \mathrm{~mm}$ and $3.8 \pm 0.2 \mathrm{~mm}$ for refined and wholegrain pasta boluses, respectively ( $\mathrm{p}=0.032$, Fig. 3 ). After NM, the swallowable bolus of wholegrain pasta was constituted with a higher proportion of small particles compared to the bolus of refined pastas containing $50 \%$ of particles larger than $4.5 \mathrm{~mm}$ (Figs. 2 and 3). With regard to the physical properties measured at the end of NM, the bolus of wholegrain pastas was harder $(\mathrm{p}=0.001)$ and more adhesive $(\mathrm{p}<$ 0.000 ) than that of the refined pastas (Table 1). Swallowable boluses of

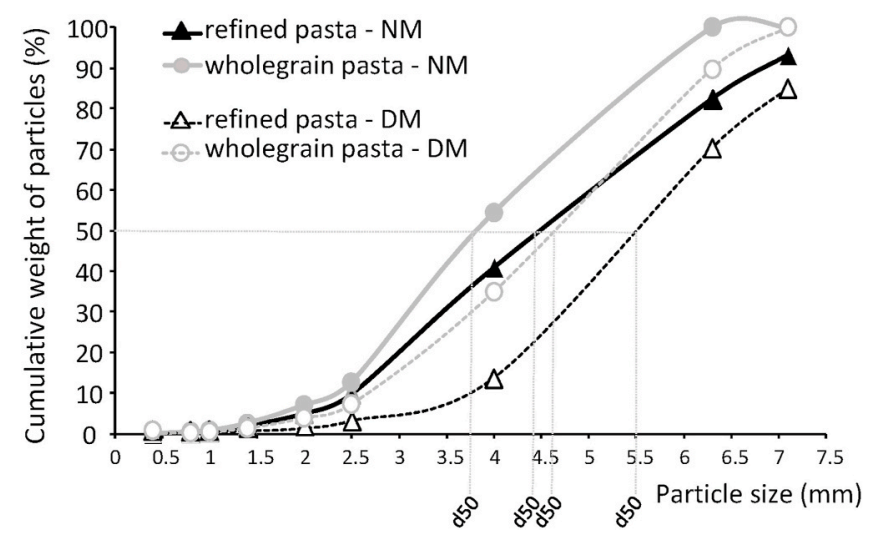

Fig. 2. Bolus particle size distribution. Particle size distribution curves were obtained for the in vitro boluses collected after normal (NM, full mark and solid line) or deficient (DM, blank symbol and dotted line) mastication performed with the masticator apparatus for refined (black) and wholegrain (grey) pastas. Curves are presented as mean cumulative weight of particles passing through each sieve $(n=8)$. For boluses containing particles larger than the greater sieve aperture, the cumulative weight did not reach $100 \%$. Median value (d50) was obtained by graphical projection for each curve. The shift towards larger particles in DM was observed for both pastas and accompanied by greater d50 values.

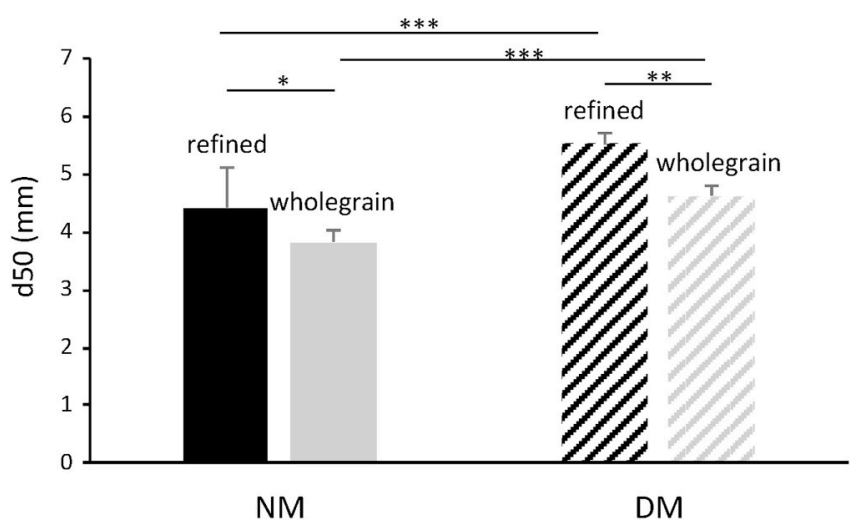

Fig. 3. Bolus median particle size. Median particle size values d50 (mean $\pm \mathrm{SD}$; $\mathrm{n}=8$ ) were obtained from the individual cumulative particle size distribution curves of the refined and wholegrain pasta boluses collected after in vitro normal (NM) or deficient (DM) mastication. ${ }^{* * *}: \mathrm{p}<0.001 ;{ }^{* *}: \mathrm{p}<0.01 ; *: \mathrm{p}$ $<0.05$.

refined and wholegrain pastas were characterized by the same level of recoverability $(\mathrm{p}>0.05)$ but the boluses of refined pastas presented a higher level of elasticity ( $\mathrm{p}=0.001$, Table 1$)$.

\subsubsection{Digestibility of starch depending on the type of pastas after normal mastication}

At the end of NM, the liquid phase of the food boluses obtained from refined and wholegrain pastas contained starch, some maltose and a very small amount of glucose (Fig. 4A, B and C). Starch was released from the pastas in saliva due to food matrix disruption. A small part of the starch released in saliva was degraded into maltose, in the same quantities (around $1.6 \mathrm{~g} / 100 \mathrm{~g}$ of pastas) for wholegrain and refined pastas ( $p>0.05$, Fig. 4B). This resulted from salivary amylolytic activity occurring during mastication, which initiated the breakdown of starch into dextrin, maltotriose and ultimately maltose, but did not lead to the production of glucose. Only a small amount of the latter was found in the boluses (less than $0.05 \mathrm{~g} / 100 \mathrm{~g}$ of pastas) whatever the type of pastas ( $\mathrm{p}$ $>0.05$, Fig. 4C).

At the end of GI digestion of food boluses resulting from NM, amounts of starch lower than $5 \mathrm{~g} / 100 \mathrm{~g}$ of pastas were found, but a significant difference was observed depending on the food matrix since higher starch contents were observed for refined pastas compared to wholegrain pastas ( $p=0.006$, Fig. 4D). Most of the initial pasta starch and maltose produced during NM were degraded into glucose, with concentrations above $50 \mathrm{~g} / 100 \mathrm{~g}$, but significantly higher for refined pastas compared with wholegrain pastas $(55.90 \pm 0.82$ and $50.80 \pm$ $0.20 \mathrm{~g} / 100 \mathrm{~g}$ of pastas, respectively, $\mathrm{p}<0.001$; Fig. 4F). The amount of residual maltose in GI digesta was not significantly affected by the type of pastas ( $\mathrm{p}>0.05$, Fig. 4E).

The oral digestibility of starch, expressed as the amount of maltose released in the food boluses compared to the initial amount of starch in pastas, was not influenced by the type of pastas under NM condition ( $p$ $>0.05$; Fig. 5A). Conversely, significantly higher GI digestibility of starch in NM was observed for refined pastas compared to wholegrain pastas $(82.51 \pm 1.21 \%$ vs $77.63 \pm 0.31 \%$, $\mathrm{p}<0.001$, Fig. 5B).

\subsection{Effect of deficient mastication on bolus properties and starch digestibility}

\subsubsection{Physical characterization of food bolus}

Particle size distribution was significantly changed in boluses produced in DM compared to NM whatever the type of pastas $(\mathrm{p}=0.001$, Fig. 2). This was substantiated for both refined and wholegrain pastas by a substantial proportion of larger particles constituting the bolus after incomplete masticatory sequences simulating DM. d50 values were 
Table 1

Mechanical characterization of in vitro food bolus. Hardness, adhesiveness, recoverability and elasticity mean values $( \pm \mathrm{SD}$ ) were obtained with a Texture Profile Analysis (TPA) test performed at $65 \%$ deformation of the initial bolus height and with a $50 \mathrm{~mm} / \mathrm{min}$ speed for the flat piston head ( $28 \mathrm{~mm}$ diameter) compressing the food bolus placed in a cylindrical cup of $35 \mathrm{~mm}$ diameter. Significance is indicated by probability observed between normal (NM) or deficient mastication (DM) values obtained for refined and wholegrain pasta, or between values obtained for refined or wholegrain pasta in a given mastication condition. NS: non significant.

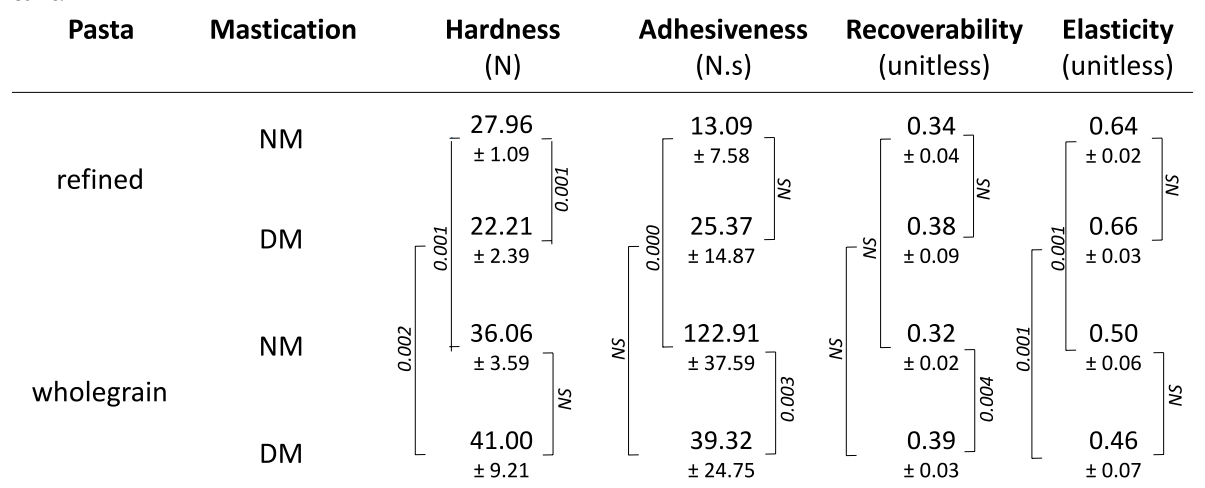

A

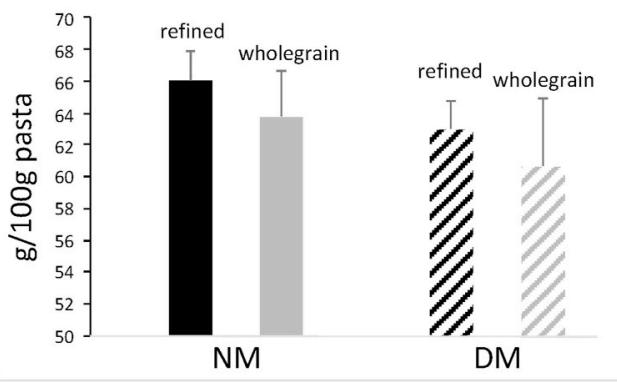

B

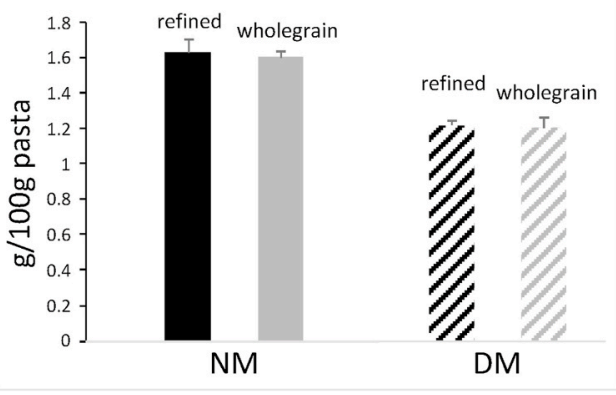

\section{Food bolus : glucose}

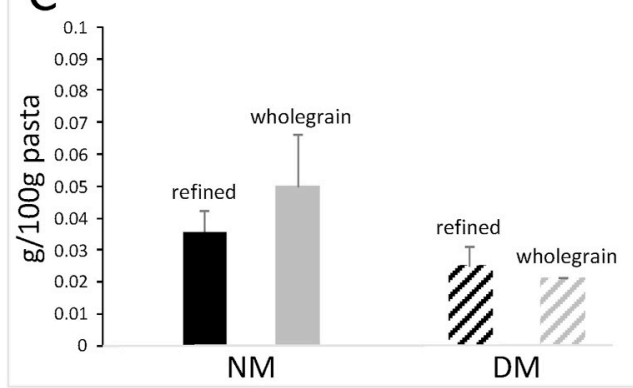

D Gl digesta: starch

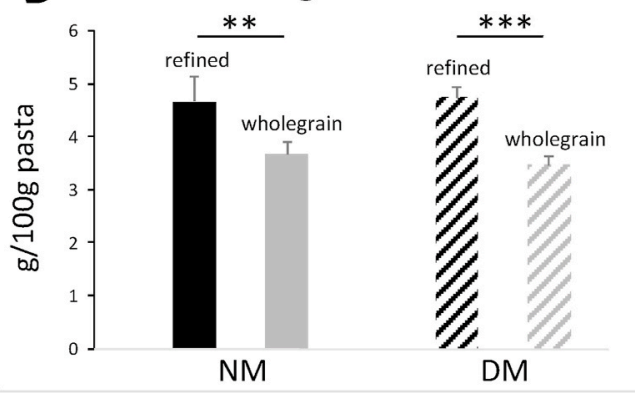

E

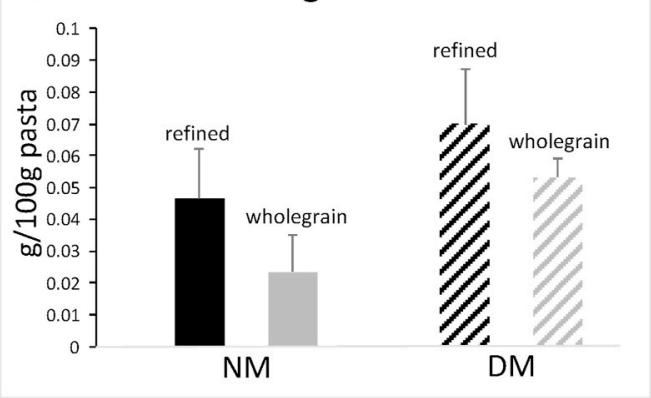

$\mathrm{F}$

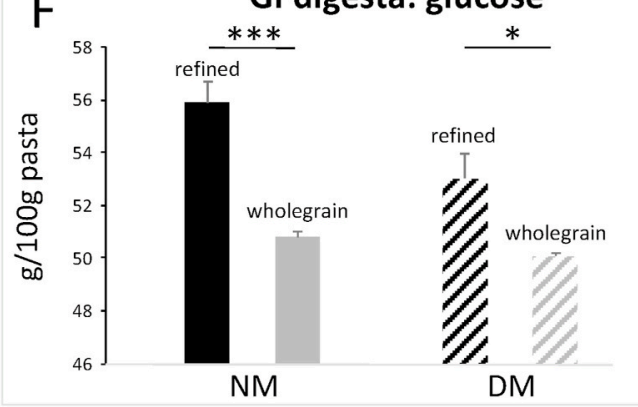

Fig. 4. Digestion of starch in food bolus and in gastrointestinal (GI) digesta. Starch, maltose and glucose contents were assayed in the liquid phase of the in vitro food bolus (A, B and $\mathrm{C}$, respectively) or GI digesta (D, E and F, respectively). Food bolus were produced in normal (NM; solid bars) or deficient (DM; hatched bars) mastication of refined (black) or wholegrain (grey) pastas. Data are expressed as the mean and standard deviation in $\mathrm{g} / 100 \mathrm{~g}$ of cooked and drained pastas (3 repetitions of mastication and/or digestion and 2 technical replicates of assay). ***: $\mathrm{p}<0.001 ;{ }^{* *}: \mathrm{p}<0.01 ; *: \mathrm{p}<0.05$. 

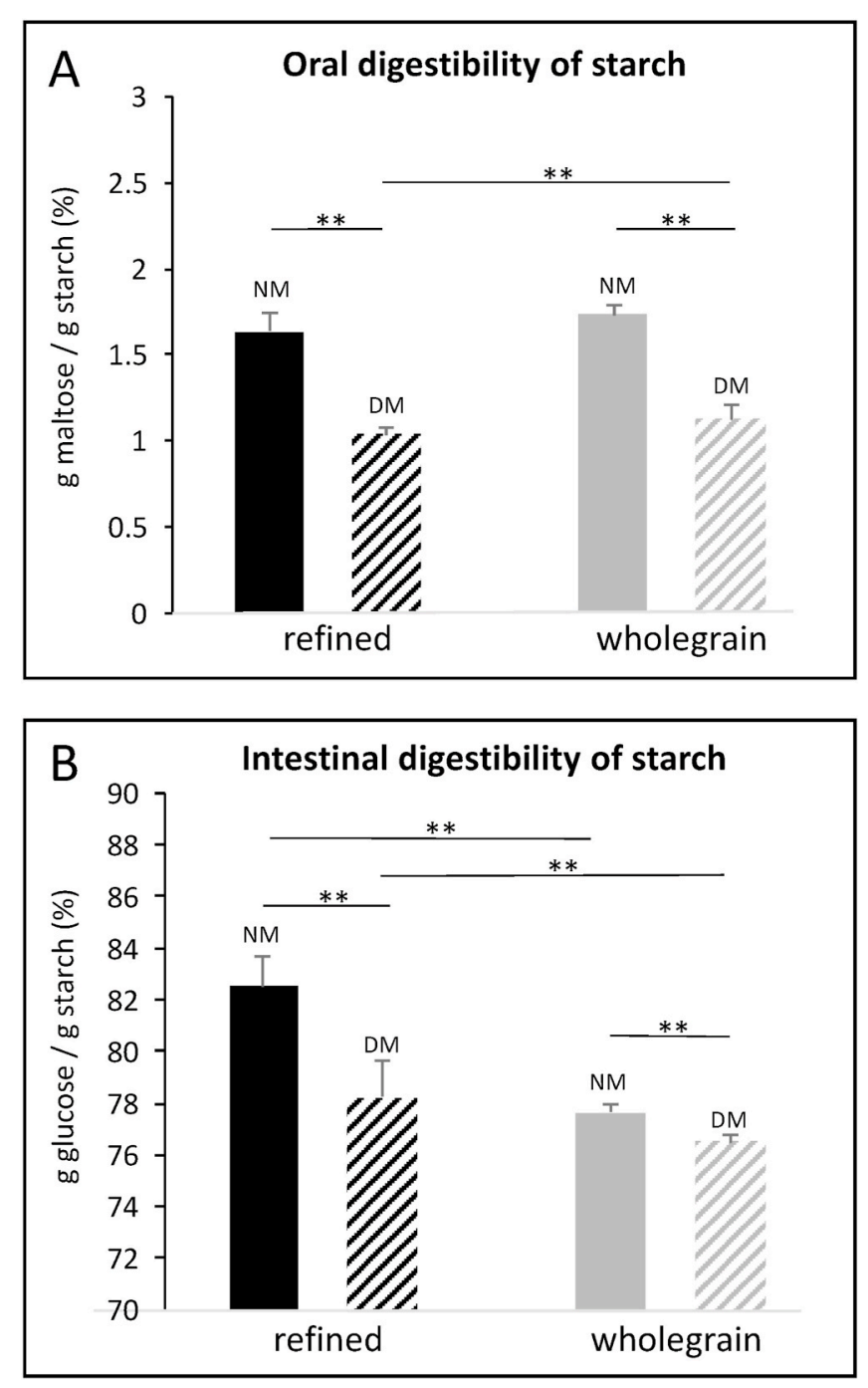

Fig. 5. Starch digestibility after mastication and after GI digestion. Oral (A) and intestinal (B) digestibility of starch was evaluated after in vitro normal (NM) or deficient (DM) mastication of refined (black bars) or wholegrain pastas (grey bars). Oral digestibility was obtained by dividing the amount of maltose, released in the liquid phase of the food bolus collected after mastication, by the amount of starch in cooked pastas. Intestinal digestibility was obtained by dividing the amount of glucose, found in the digesta after in vitro GI digestion, by the amount of starch in cooked and drained pastas. Data are expressed as mean percentages and standard deviation (3 repetitions of mastication and/or digestion and 2 technical replicates of assay). ${ }^{* *}: \mathrm{p}<0.01$.

significantly higher after DM compared to NM, reflecting an insufficiently fragmented food bolus whatever the type of pastas ( $p=0.001$ and $p=0.000$ for refined and wholegrain pastas, respectively, Fig. 3). Boluses obtained after DM presented the same level of elasticity as boluses collected after NM, whatever the type of pastas ( $p>0.05$, Table 1 ). In addition, in the case of DM, the recoverability and adhesiveness of bolus were higher $(\mathrm{p}=0.004)$ and lower $(\mathrm{p}=0.003)$ respectively, but only for wholegrain pastas.

\subsubsection{Digestibility of starch depending on masticatory efficiency}

After NM of refined and wholegrain pastas, more than $90 \%$ of the initial starch content (corresponding to at least $60 \mathrm{~g} / 100 \mathrm{~g}$ of pastas) was released in the liquid phase of the boluses (Fig. 4A). A large amount of starch was also found in food boluses from DM whatever the pastas, with only a trend to be lower for wholegrain pastas than for refined ones ( $p>$ 0.05; Fig $6 \mathrm{~A}$ and $\mathrm{D}$ ). For both refined and wholegrain pastas, the amount of maltose found in the liquid phase of the food boluses was significantly lower with DM compared to NM (1.2 g/100 g of pastas compared to 1.6 g/100 g; $\mathrm{p}<0.001$, Fig. 6B and E). Whatever the conditions (mastication efficiency and type of pastas), the amount of glucose in the liquid phase of the food boluses was very low and not significantly influenced by the efficiency of mastication ( $p>0.05$; Fig. 4C and D). For both types of pastas, the oral digestibility of starch was significantly higher under $\mathrm{NM}$ compared to DM, with over $1.5 \%$ compared to around $1 \%$ ( $\mathrm{p}=$ 0.000; Fig. 5A). Whatever the conditions (mastication and pastas), less than $5 \mathrm{~g}$ of starch per $100 \mathrm{~g}$ of pastas was found in the GI digestas (Fig. 4D). This residual amount of starch was not impacted by mastication efficiency ( $>$ > 0.05) (Fig. 6A and D). Deficient mastication of pastas led to a higher quantity of maltose in GI digesta compared to NM (significant only for wholegrain pastas, $\mathrm{p}=0.016$; Fig. 6E) and consequently a lower quantity of glucose (significant whatever the food type, $\mathrm{p}<0.01$; Fig. $6 \mathrm{C}$ and F). This led to significantly lower GI digestibility of starch ( $\mathrm{p}=0.002$, Fig. 5B) after DM of refined pastas $(78.23 \pm 1.41 \%$ vs $82.51 \pm 1.21 \%$ for $\mathrm{DM}$ and $\mathrm{NM}$, respectively) and wholegrain pastas (76.51 $\pm 0.23 \%$ vs $77.63 \pm 0.31 \%$ for $\mathrm{DM}$ and $\mathrm{NM}$, respectively).

\section{Discussion}

Using complementary in vitro mastication apparatus and static GI digestion, this work helped to pinpoint the specific level of starch digestibility in the oral cavity and in the GI tract for refined versus wholegrain pastas. Oral digestibility of starch was significantly reduced when mastication was deficient but not modified with the type of pastas. In contrast, the GI digestibility of starch was lower for wholegrain pastas even after NM, however DM caused a significant decrease in starch digestibility level (below 75\%).

\subsection{Impact of the food matrix}

Pasta is a dense matrix constituted by starch granules entrapped in a gluten network, and starch properties have been demonstrated to be important in pasta quality, just as firmness, and that can be attributed to the strength of the protein network (Delcour, Vansteelandt, Hythier, \& Abecassis, 2000). The structure of the refined and wholegrain pastas are very different due to different protein-starch network and other molecular interactions generated in wholegrain products with a high fiber content. This macromolecule organization is considered as the skeleton of the pasta structure and also account for the health benefits properties (Laleg, Barron, Santé-Lhoutellier, Walrand, \& Micard, 2016; Lu, Nishinari, Matsukawa, \& Fang, 2020). Differing in terms of structure and composition, the two pasta products tested normally led to different food oral processing (FOP) and final bolus characteristics, both depending on food structure, fracturability, food density and water content (Agrawal, Lucas, Prinz, \& Bruce, 1997; Jalabert-Malbos, Mishellany-Dutour, Woda, \& Peyron, 2007; Lucas, Prinz, Agrawal, \& Bruce et al., 2002). Indeed, after NM, the swallowable bolus of wholegrain pastas contained more fragmented particles, was harder, more adhesive and less elastic than the bolus of refined pastas.

The mechanical disruption of the pasta matrix during mastication resulted in a progressive release of starch, increasing exposure to enzyme leading to increase maltose production, the main product of starch hydrolysis by salivary alpha-amylase (Kaczmarek \& Rosenmund, 1977). This was observed with pastas in the present work with a maltose increase in the liquid phase of the bolus therefore confirming the initiation of starch hydrolysis into small glucose polymers early during mastication. The same content in maltose after oral digestion of both pastas is likely attributable to a greater oral disintegration for wholegrain pastas that probably compensated the macromolecular complexity of the matrix, ensuring a larger starch-enzyme contact surface compared to refined ones. The structure of the food matrix and the mechanics of its oral disruption are probably the main key points that may either hinder or favor exchanges with saliva enzymes, the release of nutrients during mastication and following digestive processes (Al-Rabadi et al., 2009; 


\section{A starch / refined pasta}

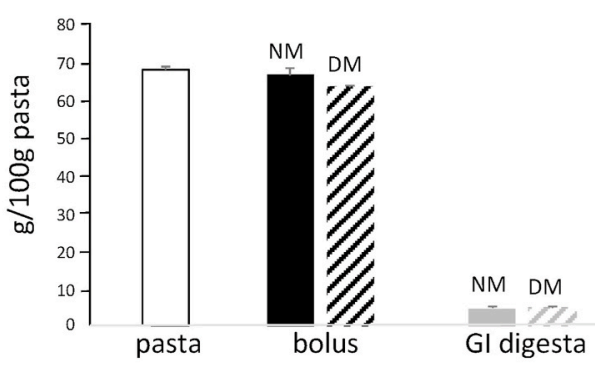

B maltose / refined pasta

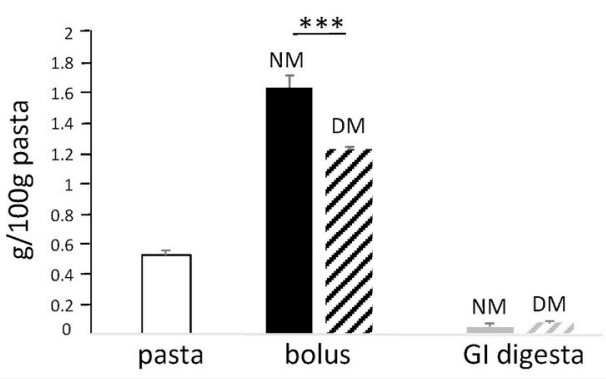

\section{C glucose / refined pasta}

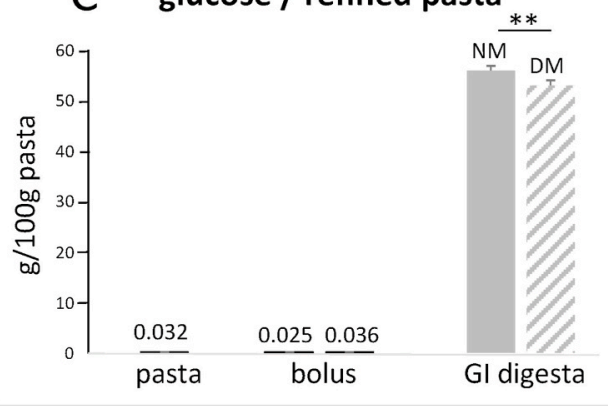

D starch / wholegrain pasta

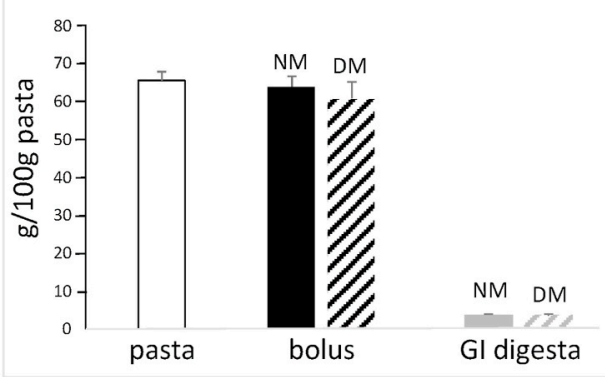

E maltose/wholegrain pasta

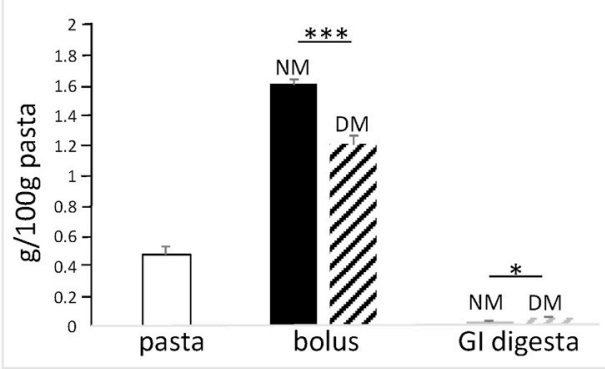

F glucose / wholegrain pasta

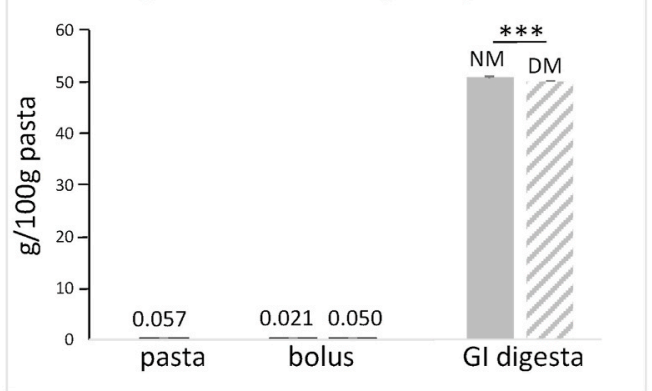

Fig. 6. Respective contributions of oral and gastro-intestinal (GI) digestion. Starch, maltose and glucose contents were determined in raw cooked and drained pastas (white bars), in the liquid phase of the in vitro food bolus (black bars) or in GI digesta (grey bars) for refined pastas (A, B and $\mathrm{C}$, respectively) or wholegrain pastas (D, E and F, respectively). Food bolus were produced in normal (solid bars) or deficient (hatched bars) mastication. Data were expressed as the mean and standard deviation in $\mathrm{g} / 100 \mathrm{~g}$ of cooked and drained pastas (3 repetitions of mastication and/or digestion and 2 technical replicates of dosage). $* * *: \mathrm{p}<0.001 ; * *$ : $\mathrm{p}<0.01 ; *$ : $<<0.05$.
Bornhorst \& Singh, 2012, 2014; Kim et al., 2008). These mechanisms are probably one major explanation for the results obtained by Hoebler et al. (1998) reporting that $50 \%$ of starch was hydrolyzed in bread bolus versus only $25 \%$ in pasta bolus. These two food boluses were also different in terms of saliva impregnation which was higher in bread bolus compared to pastas. Overall, a dense structure, the tortuosity of the protein matrix, starch entrapment, and starch- or enzyme-protein interactions have already been proposed as possible limiting factors for intestinal digestion (Zou et al., 2015). This phenomenon probably occurred for wholegrain pastas, especially because they also contain fibers expanding arrangements with proteins and starch, but the greater mechanical reduction during NM could have partially offset macromolecular inaccessibility in later stages of digestion. As suggested by other works considering the food material arriving in the stomach, both bolus particle size and viscosity influenced the rate of gastric disintegration, emptying and transit time (Bornhorst \& Singh, 2013; Guo et al., 2015; Jenkins et al., 1978; Kong \& Singh, 2008; Ranawana, Clegg, Shafat, \& Henry, 2011), as well as the glucose response related to gastric emptying rate (Mourot et al., 1988). Thus, as extensively described elsewhere, food characteristics certainly accounted for the modulation of the glycemic response at least through the degree of enzyme accessibility to starch (d'Emden, Marwick, Dreghorn, Howlett, \& Cameron, 1987; Fardet et al., 1998; Granfeldt \& Björck, 1991; Hoebler, Karinthi, Chiron, Champ, \& Barry, 1999; Jenkins et al., 1983; Kim et al., 2008; O’Dea, Nestel, \& Antonoff, 1980; Parada \& Aguilera, 2007; 2011; Stuknytè et al., 2014) but thanks to our results there is also no doubt that oral fragmentation of food must be regarded as significant. Nevertheless, it is important to emphasize that in in vitro experiments performed to study the role of food matrix on digestibility, a special attention must be payed to the bolus particle size produced. Interestingly, Aleixandre, Benavent-Gil, and Rosell (2019) showed that different in vitro food disintegration methods provided different fragmented bread boluses, which could have an effect on the kinetics of starch hydrolysis. They also highlighted that the method used for oral processing simulation could impact digestibility results.

\subsection{Consequences of deficient mastication}

After DM, the pasta bolus was still compact, insufficiently disrupted and in larger particles than after NM. Food fragmentation is directly impacted by a strong decrease in masticatory force combined with motility impairment. This is the case in ageing which is often accompanied by aggravating factors such as dental loss, causing the loss of tissues, nerves, receptors, muscles, intensifying the effect of age itself on oral sensory-motor functions, and in fine alterations in eating behavior (Peyron, Woda, Bourdiol, \& Hennequin, 2017). An impairment of dental state, changes in sensory perception, a decrease in saliva production, or other oral motor disorders impacting the food oral processing, are deleterious factors observed in various pathologies associated with damage to the oral sphere, generally leading to a deficient mastication, 
incomplete food fragmentation and low saliva impregnation (Woda, Foster, Mishellany, \& Peyron, 2006; Peyron et al., 2018).

The DM of refined and wholegrain pastas likely resulted in less saliva impregnation of the bolus, reducing food-saliva exchanges and led to weak initiation of oral digestion. Indeed, several studies highlighted that the level of starch digestion increases with a decrease in particle size (Bornhorst et al., 2013; Ranawana, Monro, Mishra, \& Henry, 2010). A thorough masticatory function produces a well-reduced and mixed bolus that can also protect salivary amylase arriving in the acidic environment of the stomach (Bornhorst et al., 2014; Butterworth, Warren, \& Ellis, 2011; Mennah-Govela, Bornhorst, \& Singh, 2015; Rosenblum, Irwin, \& Alpers, 1988). In contrast, large particles composing a deficient food bolus slowed digestive transit, that further lower or delay postprandial glucose response and glycemic index (Mourot et al., 1988; Ranawana et al., 2011; Ranawana, Leow, \& Henry, 2014; Read et al., 1986; Tan et al., 2016). Indeed, ground pasta products elicit much higher glucose and insulin peak responses than their non-mixed pasta counterparts (Granfeldt \& Björck, 1991; O'Dea et al., 1980) which strengthens the importance of oral mechanical fragmentation. Read et al. (1986) showed that swallowing starchy foods without chewing, ie without oral fragmentation, reduced postprandial glycemic and insulin responses, and even if proposed as an alternative stratagem to reduce blood glucose level, this extreme case, even if not recommended to maintain digestive well-being, interestingly confirmed the mechanisms. The consequence of mastication and food disruption for further nutrient assimilation has also been observed in other types of foods. For example, amino acids from meat with a complex structure, were less and later assimilated in edentulous people with DM than in age-matched subjects with NM (Rémond et al., 2007) Undoubtedly, this is due to a decrease in nutrient release from a food matrix insufficiently disrupted in the mouth and to macromolecules escaping enzyme action in the stomach or small intestine. In this perspective, the degree of food breakdown during mastication linked to food structure, may be considered as a full and relevant contributor to metabolism, explaining differences in nutrient absorption and glycemic variability. Thus, a DM would be detrimental to digestion and metabolism, and a proper nutritional strategy to manage disease prevention or treatment should seriously consider oral health condition in combination with food texture offer. Nutritional care must be considered in the light of potential impaired mastication and all oral disability situations. Together, the level of food breakdown is also dependent on masticatory strategies, which in turn acts on gastric emptying and nutrient release in the small intestine, better advice on thorough mastication would be an interesting means of controlling glycaemia (Tan et al., 2016). The role of food oral processing in digestion should be a key issue in the reasoning and must be used to provide adequate food structures in case of defective oral functions. Accumulating evidence suggest that food structure, processing, and mastication are significant contributors working together in the release, early digestion and bioavailability of nutrients, thus modulating metabolism. A better understanding of oral digestion mechanisms as a function of food structure as well as the consequences of an impaired mastication would provide a relevant control of potential glucose release and absorption after the ingestion of starchy foods for specific nutritional needs, especially in people with oral deficiencies.

This knowledge on oral functions must be wisely exploited in food sciences since the interpretation on the role of oral food transformation during digestion could be extended to other food components such as hydrocolloids, or dietary fibers during food process. Hydrocolloids, such as starch and proteins, and fibers if so, composing the structuring network in pastas, are undoubtedly the levers to design new foods with proper structures and required functionalities. The development of such new foods with higher control of structuring agents to obtain desirable nutritional functionalities cannot be conducted without keeping in mind the masticatory abilities of the targeted populations.

\section{Conclusion}

Overall, this study demonstrated the importance of the food oral processing in initiating starch digestion, and the consequences in case of oral deficiencies. This oral step involves at the same time food fragmentation and saliva impregnation of the fragments formed. An impaired mastication results both in a lack of fragmentation combined with less insalivation, leading to a decrease in starch hydrolysis observed in the food bolus at the moment of swallowing. Food oral processing and food structure play an important role in starch digestion during this early stage and must be seriously considered in the development of new food texture for elderly.

\section{CRediT authorship contribution statement}

S. Blanquet-Diot: Conceptualization, Methodology, Writing - original draft. O. François: Methodology. S. Denis: Methodology. M. Hennequin: Funding acquisition. M.A. Peyron: Conceptualization, Methodology, Supervision, Writing - original draft, Writing - review \& editing.

\section{Declaration of competing interest}

The authors declare that they have no known competing financial interests or personal relationships that could have appeared to influence the work reported in this paper.

\section{Acknowledgements}

The authors are grateful to M. Péron for her involvement in conducting the experiments and to L. Etienne-Mesmin for the critical reading of the manuscript.

\section{References}

d'Emden, M. C., Marwick, T. H., Dreghorn, J., Howlett, V. L., \& Cameron, D. P. (1987). Post-prandial glucose and insulin responses to different types of spaghetti and bread. Diabetes Research and Clinical Practice, 3(4), 221-226. https://doi.org/10.1016/ s0168-8227(87)80043-8.

Agrawal, K. R., Lucas, P. W., Prinz, J. F., \& Bruce, I. C. (1997). Mechanical properties of foods responsible for resisting food breakdown in the human mouth. Archives of Oral Biology, 42(1), 1-9. https://doi.org/10.1016/S0003-9969(96)00102-1.

Al-Rabadi, G. J. S., Gilbert, R. G., \& Gidley, M. J. (2009). Effect of particle size on kinetics of starch digestion in milled barley and sorghum grains by porcine alpha-amylase. Journal of Cereal Science, 50(2), 198-204. https://doi.org/10.1016/j. jcs.2009.05.001.

Alam, S. A., Pentikäinen, S., Närväinen, J., Katina, K., Poutanen, K., \& Sozer, N. (2019). The effect of structure and texture on the breakdown pattern during mastication and impacts on in vitro starch digestibility of high fibre rye extrudates. Food \& Function, 10(4), 1958-1973. https://doi.org/10.1039/C8FO02188K.

Aleixandre, A., Benavent-Gil, Y., \& Rosell, C. M. (2019). Effect of bread structure and in vitro oral processing methods in bolus disintegration and glycemic index. Nutrients, 11(9), 2105. https://doi.org/10.3390/nu11092105.

Björck, I., Granfeldt, Y., Liljeberg, H., Tovar, J., \& Asp, N. G. (1994). Food properties affecting the digestion and absorption of carbohydrates. American Journal of Clinical Nutrition, 59(3), 699S-705S. https://doi.org/10.1093/ajen/59.3.699S.

Bornhorst, G. M., Kostlan, K., \& Singh, R. P. (2013). Particle size distribution of brown and white rice during gastric digestion measured by image analysis. Journal of Food Science, 78(9), E1383-E1391. https://doi.org/10.1111/1750-3841.12228.

Bornhorst, G. M., Rutherfurd, S. M., Roman, M. J., Burri, B. J., Moughan, P. J., \& Singh, R. P. (2014). Gastric pH distribution and mixing of soft and rigid food particles in the stomach using a dual-marker technique. Food Biophysics, 9(3), 292-300. https://doi.org/10.1007/s11483-014-9354-3.

Bornhorst, G. M., \& Singh, R. P. (2012). Bolus formation and disintegration during digestion of food carbohydrates. Comprehensive Reviews in Food Science and Food Safety, 11(2), 101-118. https://doi.org/10.1111/j.1541-4337.2011.00172.x.

Bornhorst, G. M., \& Singh, R. P. (2013). Kinetics of in vitro bread bolus digestion with varying oral and gastric digestion parameters. Food Biophysics, 8(1), 50-59. https:// doi.org/10.1007/s11483-013-9283-6.

Bornhorst, G. M., \& Singh, R. (2014). Gastric digestion in vivo and in vitro: How the structural aspects of food influence the digestion process. Annual Review of Food Science and Technology, 5(1), 111-132. https://doi.org/10.1146/annurev-food030713-092346. 
Butterworth, P. J., Warren, F. J., \& Ellis, P. R. (2011). Human $\alpha$-amylase and starch digestion: An interesting marriage. Starch - Stärke, 63(7), 395-405. https://doi.org/ 10.1002/star.201000150.

Cummings, J. H., \& Englyst, H. N. (1995). Gastrointestinal effects of food carbohydrate American Journal of Clinical Nutrition, 61(4), 938S-945S. https://doi.org/10.1093/ ajcn/61.4.938S.

Delcour, J. A., Vansteelandt, J., Hythier, M.-C., \& Abécassis, J. (2000). Fractionation and reconstitution experiments provide insight into the role of starch gelatinization and pasting properties in pasta quality. Journal of Agricultural and Food Chemistry, 48(9), 3774-3778. https://doi.org/10.1021/jf991052e.

Englyst, H. N., Kingman, S. M., \& Cummings, J. H. (1992). Classification and measurement of nutritionally important starch fractions. European Journal of Clinical Nutrition, 46(Suppl 2), S33-S50.

Fardet, A., Hoebler, C., Baldwin, P. M., Bouchet, B., Gallant, D. J., \& Barry, J.-L. (1998). Involvement of the protein network in thein vitroDegradation of starch from spaghetti and lasagne: A microscopic and enzymic study. Journal of Cereal Science, 27 (2), 133-145. https://doi.org/10.1006/jcrs.1997.0157.

Freitas, D., Feunteun, S. L., Panouillé, M., \& Souchon, I. (2018). The important role of salivary $\alpha$-amylase in the gastric digestion of wheat bread starch. Food \& Function, 9 (1), 200-208. https://doi.org/10.1039/C7FO01484H.

Funami, T. (2011). Next target for food hydrocolloid studies: Texture design of foods using hydrocolloid technology. Food Hydrocolloids, 8(25), 1904-1914. https://doi. org/10.1016/j.foodhyd.2011.03.010.

Gao, Z., Fang, Y., Cao, Y., Liao, H., Nishinari, K., \& Phillips, G. O. (2017). Hydrocolloidfood component interactions. Food Hydrocolloids, 68, 149-156. https://doi.org/ 10.1016/j.foodhyd.2016.08.042.

Granfeldt, Y., \& Björck, I. (1991). Glycemic response to starch in pasta: A study of mechanisms of limited enzyme availability. Journal of Cereal Science, 14(1), 47-61. https://doi.org/10.1016/S0733-5210(09)80017-9.

Guo, Q., Ye, A., Lad, M., Ferrua, M., Dalgleish, D., \& Singh, H. (2015). Disintegration kinetics of food gels during gastric digestion and its role on gastric emptying: An in vitro analysis. Food \& Function, 6(3), 756-764. https://doi.org/10.1039/c4fo00700j.

Hoebler, C., Karinthi, A., Chiron, H., Champ, M., \& Barry, J. L. (1999). Bioavailability of starch in bread rich in amylose: Metabolic responses in healthy subjects and starch structure. European Journal of Clinical Nutrition, 53(5), 360-366.

Hoebler, C., Karinthi, A., Devaux, M.-F., Guillon, F., Gallant, D. J. G., Bouchet, B., et al. (1998). Physical and chemical transformations of cereal food during oral digestion in human subjects. British Journal of Nutrition, 80(5), 429. https://doi.org/10.1017/ S0007114598001494.

Jalabert-Malbos, M.-L., Mishellany-Dutour, A., Woda, A., \& Peyron, M.-A. (2007). Particle size distribution in the food bolus after mastication of natural foods. Food Quality and Preference, 18(5), 803-812. https://doi.org/10.1016/j. foodqual.2007.01.010.

Jenkins, D. J., Wolever, T. M., Jenkins, A. L., Lee, R., Wong, G. S., \& Josse, R. (1983). Glycemic response to wheat products: Reduced response to pasta but no effect of fiber. Diabetes Care, 6(2), 155-159.

Jenkins, D. J., Wolever, T. M., Leeds, A. R., Gassull, M. A., Haisman, P., Dilawari, J., et al. (1978). Dietary fibres, fibre analogues, and glucose tolerance: Importance of viscosity. British Medical Journal, 1(6124), 1392-1394.

Kaczmarek, M. J., \& Rosenmund, H. (1977). The action of human pancreatic and salivary isoamylases on starch and glycogen. Clinica Chimica Acta; International Journal of Clinical Chemistry, 79(1), 69-73. https://doi.org/10.1016/0009-8981(77)90462-4.

Kim, E. H.-J., Petrie, J. R., Motoi, L., Morgenstern, M. P., Sutton, K. H., Mishra, S., et al. (2008). Effect of structural and physicochemical characteristics of the protein matrix in pasta on in vitro starch digestibility. Food Biophysics, 3(2), 229-234. https://doi. org/10.1007/s11483-008-9066-7.

Kong, F., \& Singh, R. P. (2008). Disintegration of solid foods in human stomach. Journal of Food Science, 73(5), R67-R80. https://doi.org/10.1111/j.1750-3841.2008.00766. $\mathrm{X}$.

Laleg, K., Barron, C., Santé-Lhoutellier, V., Walrand, S., \& Micard, V. (2016). Protein enriched pasta: Structure and digestibility of its protein network. Food \& Function, 7 (2), 1196-1207. https://doi.org/10.1039/C5FO01231G.

Lucas, P. W., Prinz, J. F., Agrawal, K. R., \& Bruce, I. C. (2002). Food physics and oral physiology. Food Quality and Preference, 13(4), 203-213. https://doi.org/10.1016/ s0950-3293(00)00036-7.

Lu, W., Nishinari, K., Matsukawa, S., \& Fang, Y. (2020). The future trends of food hydrocolloids. Food Hydrocolloids, 103, Article 105713. https://doi.org/10.1016/j. foodhyd.2020.105713.

Mennah-Govela, Y. A., Bornhorst, G. M., \& Singh, R. P. (2015). Acid diffusion into rice boluses is influenced by rice type, variety, and presence of $\alpha$-amylase. Journal of Food Science, 80(2), E316-E325. https://doi.org/10.1111/1750-3841.12750.

Miao, M., Jiang, B., Cui, S. W., Zhang, T., \& Jin, Z. (2015). Slowly digestible starch-a review. Critical Reviews in Food Science and Nutrition, 55(12), 1642-1657. https:// doi.org/10.1080/10408398.2012.704434.

Mishellany-Dutour, A., Peyron, M.-A., Croze, J., François, O., Hartmann, C., Alric, M., et al. (2011). Comparison of food boluses prepared in vivo and by the AM2 mastication simulator. Food Quality and Preference, 22(4), 326-331. https://doi.org/ 10.1016/j.foodqual.2010.12.003.

Mourot, J., Thouvenot, P., Couet, C., Antoine, J. M., Krobicka, A., \& Debry, G. (1988). Relationship between the rate of gastric emptying and glucose and insulin responses to starchy foods in young healthy adults. American Journal of Clinical Nutrition, 48(4), 1035-1040. https://doi.org/10.1093/ajen/48.4.1035.

Nishinari, K. (2009). Texture and rheology in food and health. Food Science and Technology Research, 15(2), 99-106. https://doi.org/10.3136/fstr.15.99.

Norton, J. E., Wallis, G. A., Spyropoulos, F., Lillford, P. J., \& Norton, I. T. (2014). Designing food structures for nutrition and health benefits. Annual Review of Food
Science and Technology, 5(1), 177-195. https://doi.org/10.1146/annurev-food030713-092315.

O’Dea, K., Nestel, P. J., \& Antonoff, L. (1980). Physical factors influencing postprandial glucose and insulin responses to starch. American Journal of Clinical Nutrition, 33(4), 760-765. https://doi.org/10.1093/ajcn/33.4.760.

Parada, J., \& Aguilera, J. M. (2007). Food microstructure affects the bioavailability of several nutrients. Journal of Food Science, 72(2), R21-R32. https://doi.org/10.1111/ j.1750-3841.2007.00274.x.

Parada, J., \& Aguilera, J. M. (2009). In vitro digestibility and glycemic response of potato starch is related to granule size and degree of gelatinization. Journal of Food Science, 74(1), E34-E38. https://doi.org/10.1111/j.1750-3841.2008.01016.x.

Parada, J., \& Aguilera, J. M. (2011). Review: Starch matrices and the glycemic response. Food Science and Technology International, 17(3), 187-204. https://doi.org/10.1177/ 1082013210387712.

Pentikäinen, S., Sozer, N., Närväinen, J., Ylätalo, S., Teppola, P., Jurvelin, J., et al. (2014). Effects of wheat and rye bread structure on mastication process and bolus properties. Food Research International, 66, 356-364. https://doi.org/10.1016/j. foodres.2014.09.034.

Peyron, M.-A., Santé-Lhoutellier, V., Dardevet, D., Hennequin, M., Rémond, D., François, O., et al. (2019). Addressing various challenges related to food bolus and nutrition with the AM2 mastication simulator. Food Hydrocolloids, 97, Article 105229. https://doi.org/10.1016/j.foodhyd.2019.105229.

Peyron, M.-A., Santé-Lhoutellier, V., François, O., \& Hennequin, M. (2018). Oral declines and mastication deficiencies cause alteration of food bolus properties. Food \& Function, 9(2), 1112-1122. https://doi.org/10.1039/c7fo01628j.

Peyron, M.-A., Woda, A., Bourdiol, P., \& Hennequin, M. (2017). Age-related changes in mastication. Journal of Oral Rehabilitation, 44(4), 299-312. https://doi.org/10.1111/ joor. 12478.

Ranawana, V., Clegg, M. E., Shafat, A., \& Henry, C. J. (2011). Postmastication digestion factors influence glycemic variability in humans. Nutrition Research, 31(6), 452-459. https://doi.org/10.1016/j.nutres.2011.05.006.

Ranawana, V., Henry, C. J. K., \& Pratt, M. (2010a). Degree of habitual mastication seems to contribute to interindividual variations in the glycemic response to rice but not to spaghetti. Nutrition Research, 30(6), 382-391. https://doi.org/10.1016/j. nutres.2010.06.002.

Ranawana, V., Leow, M. K.-S., \& Henry, C. J. K. (2014). Mastication effects on the glycaemic index: Impact on variability and practical implications. European Journal of Clinical Nutrition, 68(1), 137-139. https://doi.org/10.1038/ejcn.2013.231.

Ranawana, V., Monro, J. A., Mishra, S., \& Henry, C. J. K. (2010). Degree of particle size breakdown during mastication may be a possible cause of interindividual glycemic variability. Nutrition Research, 30(4), 246-254. https://doi.org/10.1016/j. nutres.2010.02.004.

Read, N. W., Welch, I. M., Austen, C. J., Barnish, C., Bartlett, C. E., Baxter, A. J., et al. (1986). Swallowing food without chewing; a simple way to reduce postprandial glycaemia. British Journal of Nutrition, 55(1), 43-47. https://doi.org/10.1079/ bjn19860008.

Rémond, D., Machebeuf, M., Yven, C., Buffière, C., Mioche, L., Mosoni, L., et al. (2007). Postprandial whole-body protein metabolism after a meat meal is influenced by chewing efficiency in elderly subjects. American Journal of Clinical Nutrition, 85(5), 1286-1292. https://doi.org/10.1093/ajcn/85.5.1286.

Roger-Leroi, V., Mishellany-Dutour, A., Woda, A., Marchand, M., \& Peyron, M. A. (2012). Substantiation of an artificial saliva formulated for use in a masticatory apparatus. Odonto-Stomatologie Tropicale = Tropical Dental Journal, 35(138), 5-14.

Rosenblum, J. L., Irwin, C. L., \& Alpers, D. H. (1988). Starch and glucose oligosaccharides protect salivary-type amylase activity at acid $\mathrm{pH}$. American Journal of Physiology, 254 (5 Pt 1), G775-G780. https://doi.org/10.1152/ajpgi.1988.254.5.G775.

Stuknyte, M., Cattaneo, S., Pagani, M. A., Marti, A., Micard, V., Hogenboom, J., et al. (2014). Spaghetti from durum wheat: Effect of drying conditions on heat damage, ultrastructure and in vitro digestibility. Food Chemistry, 149, 40-46. https://doi.org/ 10.1016/j.foodchem.2013.10.071.

Tan, V. M. H., Ooi, D. S. Q., Kapur, J., Wu, T., Chan, Y. H., Henry, C. J., et al. (2016). The role of digestive factors in determining glycemic response in a multiethnic Asian population. European Journal of Nutrition, 55(4), 1573-1581. https://doi.org/ 10.1007/s00394-015-0976-0.

Thévenot, J., Cordonnier, C., Rougeron, A., Le Goff, O., Nguyen, H. T. T., Denis, S., et al. (2015). Enterohemorrhagic Escherichia coli infection has donor-dependent effect on human gut microbiota and may be antagonized by probiotic yeast during interaction with Peyer's patches. Applied Microbiology and Biotechnology, 99(21), 9097-9110. https://doi.org/10.1007/s00253-015-6704-0.

Woda, A., Foster, K., Mishellany, A., \& Peyron, M.-A. (2006). Adaptation of healthy mastication to factors pertaining to the individual or to the food. Physiology \& Behavior, 89(1), 28-35. https://doi.org/10.1016/j.physbeh.2006.02.013.

Woda, A., Mishellany-Dutour, A., Batier, L., François, O., Meunier, J.-P., Reynaud, B., et al. (2010). Development and validation of a mastication simulator. Journal of Biomechanics, 43(9), 1667-1673. https://doi.org/10.1016/j.jbiomech.2010.03.002.

Woda, A., Mishellany, A., \& Peyron, M.-A. (2006). The regulation of masticatory function and food bolus formation. Journal of Oral Rehabilitation, 33(11), 840-849. https:// doi.org/10.1111/j.1365-2842.2006.01626.x. 
Woda, A., Nicolas, E., Mishellany-Dutour, A., Hennequin, M., Mazille, M.-N., Veyrune, J.L., et al. (2010). The masticatory normative indicator. Journal of Dental Research, 89 (3), 281-285. https://doi.org/10.1177/0022034509357022.

Zou, W., Sissons, M., Gidley, M. J., Gilbert, R. G., \& Warren, F. J. (2015). Combined techniques for characterising pasta structure reveals how the gluten network slows enzymic digestion rate. Food Chemistry, 188, 559-568. https://doi.org/10.1016/j. foodchem.2015.05.032.

Zou, W., Sissons, M., Warren, F. J., Gidley, M. J., \& Gilbert, R. G. (2016). Compact structure and proteins of pasta retard in vitro digestive evolution of branched starch molecular structure. Carbohydrate Polymers, 152, 441-449. https://doi.org/10.1016/ j.carbpol.2016.06.016. 